(about $60 \%$ ) with $\mathrm{C} 4 \mathrm{~b}$ binding protein. The concentrations of this protein were twice the reference values but became normal after the leg was amputated and the clinical condition stabilised (day 142). This may have been due to the reactant behaviour of this protein in the acute phase. - The concentrations of free (active) protein $\mathrm{S}$ calculated from total protein $\mathrm{S}$ and $\mathrm{C} 4 \mathrm{~b}$ binding protein with a dissociation constant of $0.7 \times 10^{-} \mathrm{mol} / \mathrm{l}$ for the protein $\mathrm{S} / \mathrm{C} 4 \mathrm{~b}$ binding protein complex ${ }^{4}$ agreed with those measured. This confirmed protein $\mathrm{S}$ deficiency as we found moderately decreased concentrations of protein $\mathrm{S}$ and a shift from its free form to the complexed form with $\mathrm{C} 4 \mathrm{~b}$ binding protein.

As protein $\mathrm{S}$ is necessary for the anticoagulant activity of protein $\mathrm{C}$, a decrease in the functional concentration of protein $S$ may have the same consequences as a defect of protein C. Possibly in our patient the functional protein S deficiency was important in the pathogenesis of the skin necrosis induced by coumarin.

This work was supported by grant No 3.387-0.86 from the Swiss National Fund for Scientific Research and by the Foundation for Research on Atherosclerosis and Thrombosis.

1 McGehee WG, Klot\% TA, Epstein DJ, Rapaport SI. Coumarin necrosis associated with hereditary protein C deficiency. Ann Intern Med 1984;101: $59-60$.

2 Esmon CT. The regulation of natural anticoagulant pathwass. Sicence 1987; 235:1348-52.

3 Samama M, Horellou MH, Soria J, Conard J, Nicolas (i. Successful progressive anticoagulation in a severe protein $\mathrm{C}$ deficiencr and previous skin necrosis at the initiation of oral anticoagulant treatment. Thromb Huemost 1984:51: $132-3$.

4 Bertina RM, van Wijngaarden A, Reinalda-Poot J, Poort SR, Bom VJJ. Determination of plasma protein $\mathrm{S}$ - the protein cofactor of activated protein C. Thromb Haemost 1985:53:268-72

5 Comp PC, Doray D, Patton D, Esmon CT. An abnormal plasma distribution of protein $S$ occurs in functional protein $S$ deficiency. Blood 1986:67:504-8.

Accepted 21 October 1988

\section{Screening for hepatitis B and vaccination of homosexual men}

\author{
Richard H T Loke, Iain M Murray-Lyon, \\ Thambiah Balachandran, Brian A Evans
}

\section{Department of \\ Gastroenterology, Charing \\ Cross Hospital, London W6 8RF}

Richard H T Loke, MRCP, research fellow

Iain M Murray-Lyon, FRCP, consultant physician and gastroenterologist

\section{Department of} Genitourinary Medicine,

West London Hospital, London W6

Thambiah Balachandran, MRCP, registrar in genitourinary medicine

Brian A Evans, FRCP, consultant genitourinary physician

Correspondence to: $\mathrm{Dr}$ Murray-Lyon.

BrMed f 1989;298:234-5
Adler et al concluded that screening for and vaccination against hepatitis $B$ virus among male homosexuals were worth while and cost effective. ${ }^{1}$ The diminished response to the vaccine of homosexuals positive for HIV has, however, complicated the issue.? We conducted a postal survey to find out about the use of hepatitis $B$ vaccines and the management of hepatitis $B$ virus infection in genitourinary medicine clinics in the United Kingdom.

\section{Patients, methods, and results}

In January 1988 we posted a questionnaire to the 129 consultants in charge of all the genitourinary medicine clinics in the United Kingdom as listed in the revised list of sexually transmitted diseases clinics issued by the Department of Health and Social Security in August 1985. The 19 questions were designed to determine whether all homosexual and bisexual men attending the clinics were routinely screened for hepatitis B surface antigen; whether, if they were positive for the antigen, they routinely underwent liver function tests; and whether those with abnormal liver function were referred to a doctor with a specialist interest in hepatitis B. Other questions were aimed to assess policy on vaccination of homosexual and bisexual men without markers of hepatitis B virus infection and views on the impact of HIV infection, safer sex, and the recombinant hepatitis $B$ vaccine. The format of the questionnaire was such that we were not aware of exactly where the respondent worked.

The responses were coded according to yes, no, don't know, and no response; analysed with the statistical package for the social sciences X program; and subdivided according to whether they came from London or the rest of the United Kingdom. Altogether $121(94 \%)$ clinics replied within eight weeks; 18 of the 19 London clinics and 103 of the 110 clinics in the rest of United Kingdom responded.

Ninety eight $(81 \%)$ of the clinics screened for hepatitis B surface antigen, but, surprisingly, only 13 of the 18 London clinics did so. Sixteen of the London clinics $(89 \%)$ compared with 70 of the clinics in the rest of United Kingdom (69\%) requested liver function tests for subjects positive for hepatitis B surface antigen and referred patients with abnormal liver function, whether or not they were positive for HIV. Vaccination of subjects negative for hepatitis B surface antigen was advised in only 76 of 119 clinics. Eight of the 10 Scottish clinics but only 10 of 17 London clinics routinely advised vaccination.

Only 36 of all the clinics in the United Kingdom offered vaccination, including seven of the 10 Scottish clinics. A higher proportion (13/16) of London clinics performed tests for immunity, measuring antibodies to hepatitis B surface and core antigens before vaccination $(51 / 88)$. Over half $(63 / 120)$ of all clinics had no preference for the type of hepatitis $B$ vaccine, but among those with a preference the recombinant vaccine was the most popular (41/57). Forty five clinics did not offer vaccination because it was not available locally. Sixty three of the 75 clinics that did not offer vaccination advised their patients to seek vaccination from their general practitioners.

Sixty three clinics thought that homosexuals positive for HIV should not be vaccinated against hepatitis B. One hundred and seven thought that vaccination of susceptible homosexuals was necessary despite the onset of the AIDS epidemic, and most (93) considered it necessary even if the patient was practising safer sex. In areas where hepatits B virus and HIV are less prevalent, however, contrary views were often held.

\section{Comment}

There is a striking discrepancy between current recommendations on vaccination against hepatitis $B$ virus $^{3}$ and actual clinical practice, with noticeable differences between London and the rest of the United Kingdom. A more vigorous programme of screening and vaccination in the genitourinary medicine clinics would reduce acute and chronic hepatitis $B$ virus infection in susceptible homosexual and bisexual men. ${ }^{3}$

We thank Dr K MacRae and Mr R A Bond for advice on statistics and computing. RHTL was supported by the Bernard Sunley Charitable Foundation.

1 Adler MW, Belsey EM, McCutchan JA, Mindel A. Should homosexuals be vaccinated against hepatitis $B$ virus? Cost and benefit assessment. Br Med 7 1983;286:1621-4

2 Loke RHT, Anderson MG, Tsiquaye KN, et al. Reduced immunogenicity of recombinant yeast hepatitis $B$ vaccine in HIV-positive male homosexuals. In: Zuckerman AJ, ed. Viral hepatitis and liver disease. New York: Alan R Liss, Zuckerman $A$.

3 Joint Committee on Vaccination and Immunisation. Immunisation against infectious diseuse. London: HMSO, 1988:70-9.

(Accepted 24 October 1988) 